
Maria Zilda da Cunha

\title{
Once Upon a Time and So Many Other Times: Hansel and Gretel
}

\begin{abstract}
Fairy tales constitute a huge imaginary heritage that preserves stories whose origins bring us to the time when time could not be counted. These anonymous narratives which circulated orally, from generation to generation, have changed over time in different cultures and societies. This process of what Zumthor has called mouvance, articulated in mnemonic networks, enables the creation of intervocalization and intertextual connections, an achievement that is rendered in different semiotic systems, in a circular movement that allows exchanges, transformations, and disruption. Reinvented in different codes and languages, and on different technological platforms, these texts create new elements. From the perspective of semiotic studies and literary comparativism, we will compare the Grimms' version of the Hansel and Gretel tale, collected from oral tradition, with the audio-visual version developed by the TV series Once Upon a Time (season 1, episode 9), observing codes and adaptations in order to reflect on the rereading in the contemporary era.
\end{abstract}

Keywords: fairy tales, Hansel and Gretel, imaginary, intertextuality, Once Upon a Time (TV series)

\section{Introduction}

The fascination which men have had for narratives since time immemorial is well known. Moved by the endeavour of deciphering, men create and recreate multiple forms of language that permanently proliferate and hybridize, allowing mankind to complete itself while coming up with stories. The configuration of the several communication eras (Santaella 2005) draws on a complex mouvance/shifting, a concept coined by Zumthor (1993) to describe the creation of mnemonic networks of intervocality and intertextuality in different semiotic systems, in whose momentum it is possible to notice exchanges, transformations, and disruption. Thus, narratives produced and perpetuated orally in transit to other languages and technological platforms plot a composite of stories in the human imagination.

We have learned from Walter Benjamin (1994, 197-221) that the narrator is no longer present among us; however, the art of narrating perpetuates the need 
for exchanging experiences. The group of listeners became spectators as the craft-processes of communication, whose technology was the vocal apparatus and the body and vocal performance, became processes mediated by technological mechanisms for the diffusion of voice perpetuated in space and time, capable of reproducing verbal and written language through the development of optical techniques of image reproduction and hybrid processes of propagation of image and sound.

Recreated in different codes and languages, and for new technological platforms, the primordial narratives and their creative translations contain old and new elements - that, in the context of this article, deserve to be reviewed and analysed.

A well-known story, Hansel and Gretel is a narrative that we can hardly access in its craft production mode, that is, in performance. But the intervocality and the magic elements that move can be grasped. The children's imaginary commonly accesses this tale through the written record - via the versions of the Grimm brothers (2002) or Perrault (1973, 30-33) - or through the digital animated films that reread them. One version for an adult audience, in the TV series Once Upon a Time (OUAT), which aired its first episode on 23 October 2011, makes an interesting intertextual dialogue, rescuing yarns from several fairy tales and wonderful tales, including Hansel and Gretel. In the series, the characters are taken to another context, where there will be no happy endings and only Snow White's daughter, at the age of twenty-eight, will be able to reverse the situation by fighting the Evil Queen.

"Once upon a time there was an enchanted forest with all the classic characters we know, or we think we know" -the first episode in the series ("Pilot" 2011) begin with this sentence, in which several protagonists are presented to us in two worlds: one of magic and another of everyday life. This is because "one day they found themselves trapped in a place where all their happy endings have been stolen. Our world" ("Pilot" 2011). Thus, the series shows both sides of every story. Valenzuela $(2016,9)$ puts it thus: "The guiding idea of the OUAT screenwriters is to create a new world of classic tales, using public-domain characters from oral tradition and, later, fixed in writing by writers of fables, folk tales, and fairy tales, providing the audience with new elements that would have appeared in addition to the known facts." 1

In this article, it is our intention to carry out a comparative reading of Hansel and Gretel - in the Grimm brothers' version and in the audio-visual version as figured in the plot of the Once Upon a Time episode. We are dealing with two

1 Translations in this article are our own unless otherwise indicated. 
different narrative fields: one of literary language and another of filmic language, fields that have interesting relations between each other. To access them from the perspective of comparative literature requires an understanding of the fact that comparing the architecture of expressive forms produces a set of historical, social, and cultural elements, besides technical and aesthetic ones. Although the rapprochement between these two narrative fields - literature and cinema - is historically recognized, it is worth noting that these semiotic systems will not be compared here in the traditional way of drawing them together (searching for sources and influences in order to evaluate the process of cinematographic adaptation so as to prove "fidelity" with respect to the primary work). Instead, we shall cover the inter-art dialogue from the perspective of creative mouvance/shifting operations, examining the way the intersemiotic translations promoted in this relationship are processed.

In this context, we propose to observe and understand the relationships between literature and cinema from a broad perspective, considering the producer of the filmic work as a reader with "affective and volitional reactions, expectations, 'pre-judgements' or 'prejudice' [...] and a historical and temporal contextuality" (Sousa 2001, 33).

In this sequence of ideas, the language operations that seek to translate narrative texts from one language to another, from one medium or technological platform to another, deserve attention. According to Plaza $(2003,98)$, "the language operation from one medium to another implies a translator's awareness, one that is able to consult not only the intricacies of the nature of the new technological platform, its potential and limits, but to take, from there, the qualitative leap, i. e. to move from mere reproduction to production."

There are writings that tell that the anonymous tale of Hansel and Gretel was narrated, for a long time, on winter evenings around the fire in the huts of peasants. It became known from the Charles Perrault version, which gives written treatment to orality, and it was later rewritten in a version inspired by literary romanticism by the Grimm brothers. Given that it is impossible to interact in performance as the traditional storytellers did, and the written versions are not able to translate the spontaneous and affective effects of orality as experienced by the illiterate storytellers, who had no sense of line, punctuation, or the other resources used on printed pages, we have chosen just to signal here the existence of this narrative, which has crossed generations in permanent mouvance/shifting.

In print culture, the practical dimension of experiencing narration vanishes. Narrator and listener transfer themselves to the book object in a simulacrum of performance - artefacts. As the artist cannot make the voice heard, he trusts "to the eye the task of suggesting to the ear the sound reality" (Zumthor 1993, 125); thus, the written text becomes a "vocal gesture opportunity" (55). The image 
fixes itself. As Borges shows, the book becomes an extension of the memory of mankind, of the creative imagination and the life lived beyond appearances.

The unique work of art is now created to be reproduced within the capitalist system. Communication processes are mediated by technology. Mechanisms are developed for spreading and diffusing voice in space and time, capable of reproducing written verbal language, optical techniques of image formation, hybrid processes propagating sound and image.

Many researchers have tried to detect the sources of this literature of anonymous and collective production, but could not find the original, pure texts. These anonymous texts circulated through the Middle Ages and the Renaissance until 1634, when Giambattista Basile published, in Naples, The Tale of Tales, subtitled Pentameron, in which fairy tales are highlighted. The book contains several of the most recurrent leitmotifs that can be found in stories all over the world.

In the Renaissance (fifteenth and sixteenth centuries), the written word became a significant presence. This was a period in which Italy showed a strong interest in folklore, short stories and folk songs, since the dialects tried to impose themselves as official languages. Basile was a scholar and aristocrat who discovered among Neapolitan peasants the linguistic wonders of the regional dialect. He became famous for the discovery of the stories of enchantment that circulated among the Neapolitans. He sets Mediterranean versions of these narratives down in Neapolitan dialect in his famous Tale of Tales or Pentameron. Endowed with an excellent linguistic breadth, Basile's works were translated into nine languages.

The French concern to adapt popular stories to the taste of an eighteenth-century audience is notorious. The rediscovery of popular literature by Perrault was aimed at amusing and guiding the moral formation of children, always pointing out rules of behaviour based on bourgeois values of the time. Despite being a transmitter of the prevailing values, Perrault introduced into literature the humble people: chambermaids, butlers, cooks, and others.

Two centuries later, between 1812 and 1822, Jacob and Wilhelm Grimm collected these ancient narratives from folk memory and also put them into writing with an artistic quality. Jacob and Wilhelm were German philologists and scholars who gathered stories from the peasants of their country in order to perpetuate the medieval poetic production recorded, until then, only in the memory of the people. The nineteenth century into which the stories are inserted is marked culturally by romanticism, which brought a humanitarian sensitivity, softening the violent images.

Although the old fairy tales of our childhood continue to pronounce their magic words, the way they are told tends to change, reflecting the cultural context in which they appear. Originally inscribed in the oral heart of a people and spread by word of mouth, the tales, in the long run, have been crystallized by means 
of the written word, in works by figures such as Basile, Perrault, the Grimms, T. Braga, Câmara Cascudo, and others. Since the twentieth century, they have been transformed in the work of visual art studios and, in the twenty-first century, they are being related to new technologies and the scope of cyberculture.

\section{Hansel and Gretel: The plot of the Once Upon a Time episode}

The episode (“True North” 2012) begins in Storybrooke, with Henry reading The Incredible Hulk comic book, the story of Hulk fighting against Wolverine. Henry is in a supermarket and is heckled by Ava, one of his classmates. Then, Nicholas, Ava's brother, introduces himself to Henry. Ava invites Henry to accompany them. The market owner asks Henry to open his backpack and finds some stolen candies. Disappointed, Henry understands that Ava spoke to him just to distract him and put things in his backpack.

The scene shifts to the diegesis of the Enchanted Forest, where a lumberjack fells a tree; he is the father of the children. To ensure their safety and make sure that the family can always stay together, the father gives Gretel his compass, hanging it around her neck. After collecting some twigs, Gretel tells Hansel that it is time to return. However, their father has disappeared in the forest. During the search, they become prisoners of the Evil Queen.

Back in Storybrooke, Regina is at the supermarket to solve Henry's problem. She puts the blame on the two brothers and leaves. At the exit, she meets Emma, the town sheriff, who has been called by the shopkeeper. The phone number of the children's parents was disabled due to lack of payment, then Emma took the kids back to the house where they said they lived. But, as soon as she left them, the children ran to the place where they actually lived: the basement of an abandoned house; they had no parents.

\section{On Once Upon a Time's Hansel and Gretel episode}

The predominant theme in the traditional tale in the Grimm brothers' version is privation in its several aspects: the children feel abandoned, without the presence of their parents, and they feel the hardships of poverty and, with it, hunger. The Grimm brothers' version has as a source the folk tales of the Middle Ages and 
the hardships then experienced and transformed into narratives. Thus, the "great famine” which took place in Western Europe between 1315 and 1322 generated the production of diverse traditional tales and chronicles, among them the story of parents who leave their children in the woods, to their own fate, due to lack of food. There are also reports of cannibalism in pursuit of survival, a fact also present in the Hansel and Gretel tale, where the witch wants to devour the children: "a callousness that could have predisposed observers to think the worst murder, even cannibalism - among parents and children when a family member suddenly died or left home unobserved (disappeared) to go begging or find work. The world of famine was a world of ignorance and shadows" (Jordan 1996, 150).

In Once Upon a Time, the predominant theme in the Hansel and Gretel version is hope, reaffirming the premise of the series. However, according to Valenzuela $(2015,137)$, when analysing OUAT: “The audience that watches the episode and thinks it is a fairy tale transposed to a TV format, with the same features of a narrative intended for children, is mistaken.”

Intended for a young and adult audience, OUAT offers the opportunity to juxtapose the same characters and their narrative paths in different diegeses, one in the Enchanted Forest and another in Storybrooke, our world. Such a parallel construction allows the identification of problems which are reiterated throughout the story, leading the audience to a self-questioning attitude about their own everyday lives: facing the situation of abandonment, what attitude is to be taken? What are the institutions that deal with the vulnerable in situations of abandonment like?

In the diegesis of the Enchanted Forest, OUAT proposes a Romantic image of the family which recalls, with some modifications, the version that appears in the Grimms' first edition: in the TV episode, the children's mother has died, and it is a devoted and gentle father that takes care of the children and watches over the family's love and togetherness. The father, a lumberjack, is shown working and asks Gretel to look for branches to keep the house warm. Hansel is distracted, inattentive, indecisive, and more childish than Gretel. Despite the physical differences, the episode asserts that they are twins. When the children return in search of the father, they realize he has disappeared and try to locate him. They rely on the father, knowing that he would never abandon them, so they understand that they need to find him.

Although poor, the family displays unity, especially when the twins refuse the Evil Queen's proposal, offering them the benefits of her palace if they stay with her, leaving their father.

If we reflect on the characters present in the Grimms' tale and in the diegesis of the Enchanted Forest, we can observe a parallel with the historical reports of the Renaissance that conceive early childhood as a period of learning: 


\begin{abstract}
Early childhood was a time for learning. The toddler explored its home, its village, and the surrounding countryside. [...] The experience of childhood and adolescence was supposed to strengthen the body, sharpen the senses, equip the child to deal with adversity, and above all prepare him or her in due course to become a parent. The influence of the community made every child a product of the group and equipped him or her to do what society expected. In such circumstances there was little intimacy, but a growing sense of belonging, for better or worse, to an extended family. (Gélis 2003, 312-313)
\end{abstract}

By bringing the narrative path of lonely children to Storybrooke, the topic is given a profile close to the reality shared by the audience of the series: childhood and abandonment, the institutions that care for children in a situation of abandonment, and policies that allow the separation of siblings in the case of adoption or shelter in institutions.

According to A. Farge, who portrays the situation of Paris in the eighteenth century, the reality of child abandonment was concentrated in the disadvantaged layers of society: "The number of abandoned children is impressive, and the foundling asylum is nothing more than a desolate refuge where diseases and mortalities organize a tenacious destruction" $(1997,581)$.

The paths of the episode's narrative add to the Grimms' traditional tale the questioning of the minor's vulnerability in a situation of abandonment, a recurring problem throughout history. In OUAT, both the heroine Emma and her son Henry face the same situation and its consequences. "Vulnerability" is understood as a situation connected "to the idea of fragility and dependence, which connects to the situation of children and adolescents, especially those from lower socioeconomic backgrounds. [...] In certain situations, the state of vulnerability may affect health, even in the absence of disease" (Fonseca et al. 2013).

In the Enchanted Forest, Hansel and Gretel decide to follow the orders of the Evil Queen to steal a magical element from the Blind Witch's house, because they believe it would be the only way to see their father again. The Queen warns that one should not touch anything in the house, but Hansel ignores the warning and devours a piece of candy. Hansel succumbs easily to the candy's temptation, which marks his naivety or the hunger he was feeling. The image of the Evil Queen, offering the children a wealthy life, associated with the Blind Witch, who exposes the food, refers to the Christian fight against the devil, in which Jesus is tempted by the devil to eat and break his fast (first temptation) and the devil shows Jesus all the kingdoms and the glory that will be given if he gives in to the third temptation.

In both OUAT narratives, the children steal and lie in order to be together with their father again, who represents a guarantee of balance within life in society. Without him, the children were afraid of being separated through internment in orphanages or foster homes. The "saviour" Emma understands the children's sit- 
uation and pities them; within the fantastic scope of Storybrooke, Emma proposes real solutions to deal with recurrent conflicts in the audience's real world.

The audience shares knowledge that is despised by Emma: the children cannot leave Storybrooke since they are under the Evil Queen's curse. This condition is part of the creation of this fantastic universe of Storybrooke:

The fantastic text must rely on the assumption of a "real" world, on what we understand as "reality", codified by our laws of reason and social conventions. Several literary devices are employed to convey this impression of veracity or authenticity, one of these being the use of spatial markers in descriptions and of real spatial referents. Because it is presented as an exception within the textual reality and thus disrupts the logic that rules that storyworld, the fantastic element or event always generates a conflict. This contrasts with other literary forms in which the supernatural is an accepted part of the codes ruling the storyworld. (García 2015, 16)

\section{Final considerations}

In our view, OUAT is based on the concept of hope. The Hansel and Gretel fairy tale, in the Grimm brothers' first version from 1812, reveals, at the same time, a mild reading of the harsh medieval reality of abandonment and child poverty, softened by a veil of wonder: the happy ending is perpetuated with the death of the child-devouring witch by fire. Evil is destroyed, expunged through purification by the element of fire. It remains, then, for the twins to survive, together and free of all evil:

The old woman in the hot oven began to cry and to wail, but Gretel ran away, and the old woman burned up miserably. Gretel ran to Hansel and unlocked his door. He jumped out, and they kissed each other and were overjoyed. The whole house was filled with precious stones and pearls. They filled their pockets, then ran away and found their way back home. The father rejoiced when he saw them once more, for he had not had a happy day since they had been gone, and now he was a rich man. However, the mother had died. (Grimm and Grimm 2002 [1812 version])

There is no punishment for the children who took for themselves the riches of the witch, and no punishment for the longing and regretful father, who receives them merrily; but the tale shows no mercy for the mother who chose to abandon her children to their own fate.

In the Enchanted Forest, there is no mother, just the zealous father who is captured and suffers from the forced absence of the children. The Evil Queen aims to steal the magic apple and uses the children as an instrument to fool the Blind Witch, who is physically punished for her wickedness, as is often the case with 
popular characters, be they Romantic or from oral tradition: blindness is her negative, scary mark. The children resist committing illegal actions, but the Queen's blackmail forces the minors to steal and throw the Blind Witch into the oven. It should be noted that the fire that kills the Blind Witch is lit by the Evil Queen, and not by the children. This narrative option is in accordance with expectations about a series that is aired in the US on Sundays at 8 p.m., and thus as a family programme. It is therefore necessary to remove the children's responsibility for a death, even if it is connected to the universe of wonder.

On the other hand, there is no happy ending in the Enchanted Forest, as the Evil Queen imposes her curse and the family finds itself unable to get together again. This is the function of the heroine Emma in the diegesis of Storybrooke: in "our world," the solution backed by law is the one in which children go to an institution that deals with the vulnerable in a situation of abandonment. The mayor makes use of statutes and laws governing the situation, without thinking about the possibility of reuniting the family, trying to find out who the unknown father is. Emma takes this mission on herself, this time as a "saviour" of the family, since she herself stayed and accepted the challenge of remaining in the city in order to get closer to her son Henry, who was given up for adoption as soon as he was born and had been adopted by Regina, the Enchanted Forest's Evil Queen.

In the diegesis of Storybrooke, the audience identifies the constitution of the contemporary family according to Oliveira:

The composition [of the family] may vary between consensual unions of separated or divorced partners; same-sex unions; unions of people with children from other marriages; mothers alone with their children; grandparents with grandchildren; and a multitude of forms to be defined, putting us in front of a new family, distinct from the classic nuclear family template. (Oliveira 2009, 68)

The monoparental template of the man who discovers himself as the father of two children offers the possibility of a happy ending for the characters of the narrative core, punished by the solitude imposed by the Evil Queen's curse. After so many setbacks, the family's unification suggests a cathartic effect on the audience, and - why not - even on the Emma character who, while relating her own traumatic experience of giving the child up for adoption, undergoes a cathartic effect, a purification of emotions, from the point of view of Freudian psychology.

The interest that the Once Upon a Time series generates in the audience is precisely this possibility of catharsis as a purge, creating the double idea that we are stuck to a curse - everyday life - but that if we face that challenge based on hope, it is possible that each one of us can figure out what we are and what we could be. 


\section{Works cited}

Benjamin, Walter. Magia e técnica, arte e política: Ensaios sobre literatura e história da cultura. Trans. Sérgio Paulo Rouanet. 7th ed. São Paulo: Brasiliense, 1994.

Farge, Arlette. "Famílias: A honra e o sigilo." História da vida privada. Vol. 3. Ed. P. Ariès and R. Chartier. Trans. Hildegard Feist. São Paulo: Cia. das Letras, 1997. 559-594.

Fonseca, Franciele Fagundes, Ramony Kris R. Sena, Rocky Lane A. dos Santos, Orlene Veloso Dias, and Simone de Melo Costa. "As vulnerabilidades na infância e adolescência e as políticas públicas brasileiras de intervenção." Revista Paulista pediatria 31.2 (2013): 258-264. http://www.scielo.br/scielo.php?script=sci_arttext\&pid=S0103-05822013000200019\&lng=en\&nrm=iso (6 July 2016).

García, Patricia. Space and the Postmodern Fantastic in Contemporary Literature: The Architectural Void. New York: Routledge, 2015.

Gélis, Jacques. "The Child: From Anonymity to Individuality." A History of Private Life: Passions of the Renaissance. 7th ed. Vol. 3. Ed. P. Ariès and R. Chartier. Cambridge and London: Belknap Press of Harvard University, 2003. 309-326.

Grimm, Jacob, and Wilhelm Grimm. Hansel and Gretel. 1812, 1857. Trans. D. L. Ashliman. 2002. http://www.pitt.edu/ dash/grimm015a.html (6 July 2016).

Jordan, William C. The Great Famine: Northern Europe in the Early Fourteenth Century. Princeton: Princeton University Press, 1996.

Oliveira, Nayara H. D. Recomeçar: Família, filhos e desafios. São Paulo: UNESP/Cultura Acadêmica, 2009. http://books.scielo.org/id/965tk/pdf/oliveira-9788579830365-03.pdf (7 July 2016).

Perrault, Charles. Contos de fadas. Trans. and adapt. Monteiro Lobato. 10th ed. São Paulo: Brasiliense, 1973.

“Pilot." Once Upon a Time. 1st season, 1st episode. ABC/Disney. 23 October 2011.

Plaza, J. Tradução intersemiótica. São Paulo: Perspectiva, 2003.

Santaella, Lucia. Por que as comunicações e as artes estão convergindo? São Paulo: Paulus, 2005.

Sousa, Sérgio Paulo Guimarães de. Relações intersemióticas entre o cinema e a literatura: A adaptação cinematográfica e a recepção literária do cinema. Braga: Universidade do Minho, 2001.

"True North." Once Upon a Time. 1st season, 9th episode. ABC/Disney. 15 January 2012.

Valenzuela, Sandra Trabucco. "Once upon a Time: 0 insólito amor do anão e da fada." Entre fadas e bruxas: $O$ mundo feérico dos contos para crianças e jovens. Ed. E. Debus and R. Michelli. Rio de Janeiro: Dialogarts, 2015. 131-146.

Valenzuela, Sandra Trabucco. Once upon a Time: Da literatura para a série de TV. São Paulo and Lisbon: Chiado, 2016.

Zumthor, P. A letra e a voz: A “literatura" medieval. Trans. Amálio Pinheiro and Jerusa Pires Ferreira. São Paulo: Companhia das Letras, 1993. 
Professor Sandra Trabucco Valenzuela, $\mathrm{PhD}$, has a postdoctoral degree in Comparative Literature from the University of São Paulo (USP) and a doctorate and a master's degree in Spanish-American Literature from USP, is an expert in art history, and has a bachelor's degree and a degree in Literature (USP). Since 1998, she has been a lecturer at the School of Communication at Anhembi Morumbi University in São Paulo. She is an author of books and scholarly articles and also a broadcasting producer at Radio Mega Brasil Online.

Maria Auxiliadora Fontana Baseio holds a postdoctoral degree in Literature from Universidade do Minho, and a PhD and master's in Literature, both from Universidade de São Paulo (USP). She is a professor at Universidade de Santo Amaro, São Paulo, Brazil, in the Human Sciences Department.

Maria Zilda da Cunha holds a postdoctoral degree in Literature from Universidade de Minho, a PhD in Comparative Literature from Universidade de São Paulo, and a master's in Communication and Semiotics from Pontificia Universidade Católica - São Paulo. She is a professor at Universidade de São Paulo, in the Comparative Literature Department. 
